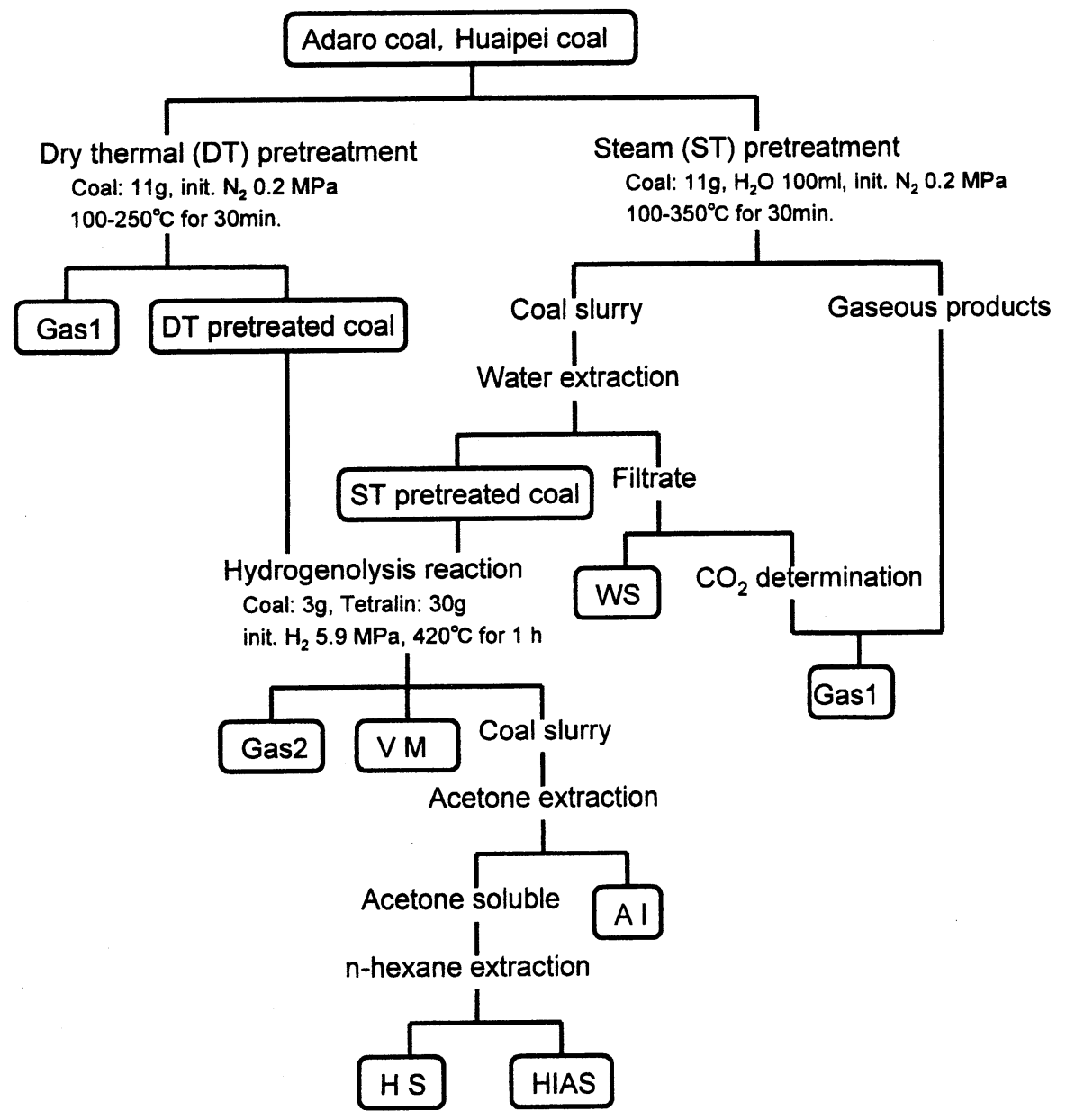

Fig. 1 Experimental scheme

Table 1 Analytical data of raw coals (wt.\%)

\begin{tabular}{|c|c|c|c|c|c|c|c|}
\hline & \multicolumn{6}{|c|}{ Ultimate analyses ${ }^{1)}$} & \multirow[t]{2}{*}{$\operatorname{Ash}^{2}$} \\
\hline & $\mathrm{C}$ & $\mathrm{H}$ & $\mathrm{N}$ & $\mathrm{O}^{3)}$ & $\mathrm{H} / \mathrm{C}$ & $\mathrm{O} / \mathrm{C}$ & \\
\hline Adarocoal & 67.5 & 5.2 & 0.8 & 26.5 & 0.92 & 0.29 & 1.5 \\
\hline Iuaipei coal & 84.3 & 5.2 & 1.1 & 9.4 & 0.73 & 0.08 & 8.8 \\
\hline
\end{tabular}

1) d.a.f. basis 2) dry basis 3) by difference

費量を求めた。これを処理水に溶解した $\mathrm{CO}_{2}$ 量とし, 前述の気体生成物量との合計をガス収率（Gas1）と した。ろ液から水を除去した後， $110{ }^{\circ} \mathrm{Cで} 1$ 時間真空 乾燥して水可溶分（WS）を得た。

\section{3 水素化分解反応}

$110{ }^{\circ} \mathrm{C} て ゙ 3$ 時間真空乾燥した処理炭 $3 \mathrm{~g}$, およびテト ラリン $30 \mathrm{~g}$ を内容積 $100 \mathrm{ml}$ のオートクレーブに充填 し, 水素初圧 $5.9 \mathrm{MPa}, 420^{\circ} \mathrm{C}, 1$ 時間の水素化分解
反応を行った。冷却後, 気体生成物（Gas2）を捕集 し，内容物をアセトンにより回収，乃過した。残渣は $110{ }^{\circ} \mathrm{C}$ で 2 時間真空乾燥しアセトン不溶分 (AI) とし た。一方，ろ液からアセトンを除去したものを超音波 照射下, n-へキサンにより抽出, ろ過し, その残渣を $60{ }^{\circ} \mathrm{C}$ で 2 時間真空乾燥しへキサン不溶アセトン可溶 分 (HIAS) とした。ヘキサン可溶分 (HS) 収率は, 石炭仕达量から上記の生成物 (Gas2 + HIAS + AI) 合計量を差し引いて求めた。

\section{4 分 析}

石炭の加熱, 水蒸気処理, および水素化分解反応に おける気体生成物の GC 分析は, Porapak N (Waters 社製），および BMEE（島津製作所社製）を充填した カラム (それぞれ $2 \mathrm{~m}, 7 \mathrm{~m})$ ，および TCD 検出器を備 
えた GC-9A（島津製作所社製）を用いて定量した。 加熱, および水蒸気処理炭の- $\mathrm{COOH},-\mathrm{OH}$ 基含有率 は，2N酢酸バリウム水溶液の代わりに $3 \mathrm{~N}$ 酢酸ナ卜 リウム水溶液を使用した以外は既報 ${ }^{3)}$ と同じ方法に 上り求めた。水素化分解反応により得られた HS 成分 の ${ }^{1} \mathrm{H}-\mathrm{NMR}$ スペクトルは，ヘキサン抽出によるろ液

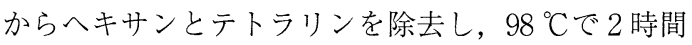
真空乾燥したものを JNM-EX90A 型 FT-NMR 装置 (90 MHz，日本電子社製)により測定した。

\section{3. 結 果}

\section{1 加熱, 水蒸気前処理}

原炭の前処理における $\mathrm{CO}_{2}, \mathrm{CO}, \mathrm{Gas} 1, \mathrm{WS}$ の各収 率, および各処理温度におけるオートクレーブ圧力を Table 2 に示した。前処理炭の-COOH, - $\mathrm{OH}$ 基含有率, 㧍よび $\mathrm{H} / \mathrm{C}$ と $\mathrm{O} / \mathrm{C}$ 原子比を Table 3 に示した。Adaro 炭では前処理温度の上昇に伴い, $\mathrm{CO}_{2}$, Gasl, WS の収 率は増加し, 酸性官能基含有率, および原子比は減少
した。これらの值の変化量は処理方法により異なり, $350{ }^{\circ} \mathrm{C}$ の水蒸気処理による $\mathrm{CO}_{2}$ 収率は $4.3 \%$ であった が，250 ${ }^{\circ} \mathrm{C}$ 加熱処理では $9.9 \%$ \%あった。 $300{ }^{\circ} \mathrm{C} の$ 水蒸気処理により, $-\mathrm{COOH},-\mathrm{OH}$ 基含有率はそれぞ れ 3.2, $2.8 \%$ 残存したが， $250{ }^{\circ} \mathrm{C}$ の加熱処理により - $\mathrm{COOH}$ 基は消失し， $-\mathrm{OH}$ 基含有率も $0.9 \%$ に著しく 減少した。しかしながら, $350^{\circ} \mathrm{C}$ の水蒸気処理では石 炭の-OH 基含有率はいずれもわずかに減少したに過 ぎない。原炭と比べて, $\mathrm{H} / \mathrm{C}, \mathrm{O} / \mathrm{C}$ 值は加熱処理によ り顕著に減少し, $250{ }^{\circ} \mathrm{C}$ 加熱処理炭では, H/C: 0.67, O/C: 0.12 となった。一方, 水蒸気処理ではこれらの 值は緩やかに減少し, $350{ }^{\circ} \mathrm{C}$ 水蒸気処理炭では, $\mathrm{H} / \mathrm{C}$ : 0.82, O/C: 0.20 にとどまった。以上の Adaro 炭の結果 と比べて, Huaipei 炭の各前処理における上述した值 は小さく，処理温度による変化もほとんど見られなか った。

いずれの石炭の水蒸気処理に扔いても, $\mathrm{CO}_{2}$ 収率と Gas1 收率の差はわずかであった。一方，加熱処理に

Table 2 Pressure at pretreatment temperature, and the yields of $\mathrm{Gas} 1, \mathrm{CO}_{2}, \mathrm{CO}$ and WS during the pretreatments of coals (wt.\% d.a.f. raw coal basis)

\begin{tabular}{|c|c|c|c|c|c|c|c|c|c|c|}
\hline & \multicolumn{5}{|c|}{ Adaro coal } & \multicolumn{5}{|c|}{ Huaipei coal } \\
\hline & Press. ${ }^{1)}$ & Gas1 & $\mathrm{CO}_{2}$ & $\mathrm{CO}$ & WS & Press. ${ }^{1)}$ & Gas1 & $\mathrm{CO}_{2}$ & $\mathrm{CO}$ & WS \\
\hline DT $150{ }^{\circ} \mathrm{C}$ & 1.6 & 1.4 & 1.2 & 0.2 & - & 0.9 & 0.1 & 0.1 & 0.0 & - \\
\hline $200{ }^{\circ} \mathrm{C}$ & 3.9 & 6.2 & 4.9 & 0.5 & - & 0.9 & 0.1 & 0.1 & 0.0 & - \\
\hline $250{ }^{\circ} \mathrm{C}$ & 4.7 & 12.5 & 9.9 & 0.7 & - & $1.7^{2)}$ & $1.5^{2)}$ & $0.5^{2)}$ & $0.2^{2)}$ & - \\
\hline $\mathrm{ST} 150^{\circ} \mathrm{C}$ & 0.4 & 0.1 & 0.1 & 0.0 & 0.0 & 0.4 & 0.0 & 0.0 & 0.0 & 0.0 \\
\hline $200{ }^{\circ} \mathrm{C}$ & 1.5 & 0.1 & 0.1 & 0.0 & 1.0 & 1.2 & 0.0 & 0.0 & 0.0 & 0.6 \\
\hline $250{ }^{\circ} \mathrm{C}$ & 3.4 & 0.5 & 0.5 & 0.0 & 1.4 & 2.9 & 0.4 & 0.4 & 0.0 & 0.6 \\
\hline $300{ }^{\circ} \mathrm{C}$ & 7.8 & 3.1 & 2.9 & 0.2 & 2.0 & 7.8 & 0.7 & 0.7 & 0.0 & 1.2 \\
\hline $350{ }^{\circ} \mathrm{C}$ & 12.8 & 4.6 & 4.3 & 0.3 & 2.9 & 12.8 & 1.0 & 1.0 & 0.0 & 0.5 \\
\hline
\end{tabular}

1) Pressure (MPa) at pretreatment temperature 2) Pretreatment temperature : $235^{\circ} \mathrm{C}$

Table 3 Contents of $-\mathrm{COOH}$ and $-\mathrm{OH}$ groups and the ratio of $\mathrm{H} / \mathrm{C}$ and $\mathrm{O} / \mathrm{C}$ in pretreated coals (wt.\% d.a.f. pretreated coal basis)

\begin{tabular}{|c|c|c|c|c|c|c|c|c|}
\hline & \multicolumn{4}{|c|}{ Adaro coal } & \multicolumn{4}{|c|}{ Huaipei coal } \\
\hline & $-\mathrm{COOH}$ & $-\mathrm{OH}$ & $\mathrm{H} / \mathrm{C}$ & $\mathrm{O} / \mathrm{C}$ & $-\mathrm{COOH}$ & $-\mathrm{OH}$ & $\mathrm{H} / \mathrm{C}$ & $\mathrm{O} / \mathrm{C}$ \\
\hline Raw coal & 5.5 & 4.2 & 0.92 & 0.29 & 0.0 & 0.2 & 0.73 & 0.08 \\
\hline DT $150^{\circ} \mathrm{C}$ & 6.5 & 4.1 & 0.85 & 0.22 & 0.0 & 0.7 & 0.72 & 0.07 \\
\hline $200{ }^{\circ} \mathrm{C}$ & 1.2 & 4.9 & 0.71 & 0.15 & 0.0 & 0.8 & 0.71 & 0.08 \\
\hline $250^{\circ} \mathrm{C}$ & 0.0 & 0.9 & 0.67 & 0.12 & $0.0^{1)}$ & $0.0^{1)}$ & $0.63^{1)}$ & $0.07^{1)}$ \\
\hline ST $150^{\circ} \mathrm{C}$ & 4.7 & 3.0 & 0.92 & 0.28 & 0.0 & 0.8 & 0.72 & 0.09 \\
\hline $200{ }^{\circ} \mathrm{C}$ & 5.5 & 3.0 & 0.92 & 0.27 & 0.0 & 0.4 & 0.72 & 0.09 \\
\hline $250{ }^{\circ} \mathrm{C}$ & 4.0 & 3.1 & 0.88 & 0.25 & 0.0 & 0.4 & 0.71 & 0.09 \\
\hline $300^{\circ} \mathrm{C}$ & 3.2 & 2.8 & 0.89 & 0.24 & 0.0 & 0.4 & 0.71 & 0.09 \\
\hline $350^{\circ} \mathrm{C}$ & 3.9 & 1.9 & 0.82 & 0.20 & 0.0 & 0.1 & 0.73 & 0.11 \\
\hline
\end{tabular}

1) Pretreatment temperature $: 235{ }^{\circ} \mathrm{C}$ 
おけるその差は, Adaro 炭 $\left(250{ }^{\circ} \mathrm{C}\right)$, Huaipei 炭 $\left(235{ }^{\circ} \mathrm{C}\right)$ では，それぞれ $2.6 ， 1.0 \%$ であった。これ らの差に相当するガス生成物は, $\mathrm{CH}_{4}, \mathrm{CO}, \mathrm{C}_{2} \mathrm{H}_{6}$, $\mathrm{C}_{3} \mathrm{H}_{8}$ であった。いずれの前処理においても，処理温 度の上昇に伴い，オートクレーブ圧力は増加した。 Adaro 炭の加熱処理に打ける圧力は Huaipei 炭よりも 高く, 両炭の各温度での水蒸気処理における圧力の差 は少なかった。

\section{2 前処理炭の水素化分解反応}

Adaro 炭, Huaipei 炭の前処理炭の水素化分解反応 による生成物収率を前処理炭基準にてそれぞれ Fig. 2,

Fig. 3 に示した。Adaro 炭の $150^{\circ} \mathrm{C}$ 以下, Huaipei 炭の $200{ }^{\circ} \mathrm{C}$ 以下の加熱処理, および両炭の $250{ }^{\circ} \mathrm{C}$ 以下の水 蒸気処理により得られた前処理炭の水素化分解反応収 率はそれぞれの原炭の収率と比べて変化が見られなか った。200 $\mathrm{C}$ 加熱処理炭の水素化分解反応による収率 をそれぞれの原炭の值と比べると, Huaipei 炭にはほ とんど変化が見られないが，Adaro 炭では AIが10\%

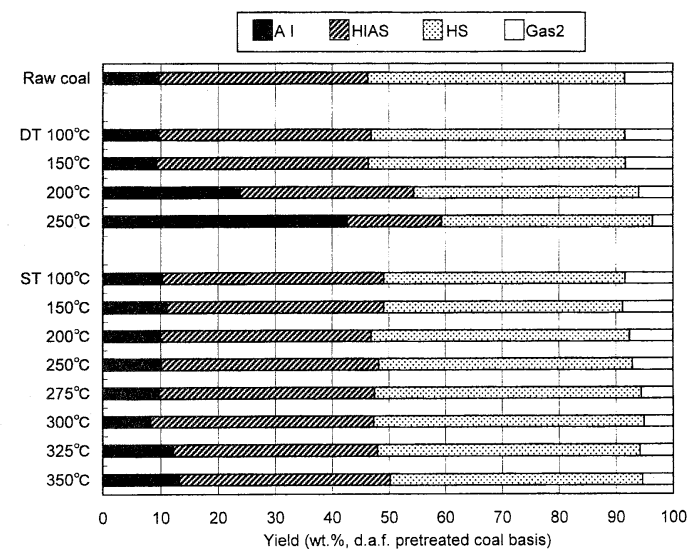

Fig. 2 Effects of pretreatments on the hydrogenolyses of Adaro coal

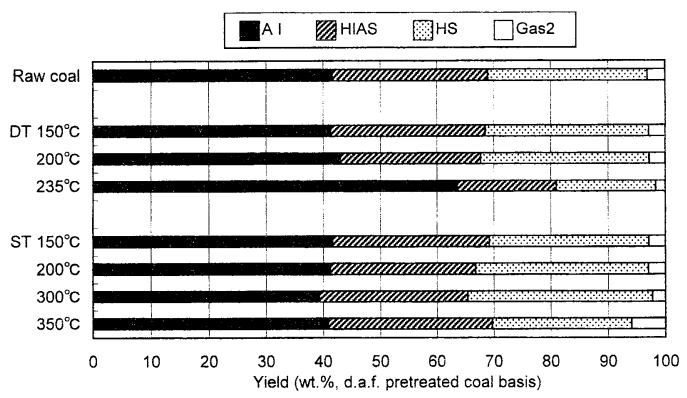

Fig. 3 Effects of pretreatments on the hydrogenolyses of Huaipei coal
から 25\% に増加し, HS と HIAS は減少した。Adaro 炭 $\left(250{ }^{\circ} \mathrm{C}\right)$, および Huaipei 炭 $\left(235{ }^{\circ} \mathrm{C}\right)$ 加熱処理炭 の水素化分解反応では，それぞれの原炭の反応により HIASとして分別された成分の多くがAI となり，軽 質化の抑制されることが分かった。一方，水蒸気処理 炭の水素化分解反応では，そのような軽質化の抑制は 起こらなかった。特に $300{ }^{\circ} \mathrm{Cで}$ 水蒸気処理したいずれ の石炭の水素化分解反応においては，わずかにAIの 減少する軽質化が見られた。しかしながら，その軽質 化反応は, $325^{\circ} \mathrm{C}$ 以上の水蒸気処理炭の水素化分解反 応では現れなかった。

$\mathrm{HS}$ 成分の単位構造の芳香族性指数（fa）を Brown - Ladner 法 ${ }^{18)}$ に従い, HS の元素分析值と ${ }^{1} \mathrm{H}-\mathrm{NMR}$ スペクトルから計算した。HSの fa 值，およ び $\mathrm{H} / \mathrm{C} と \mathrm{O} / \mathrm{C}$ 原子比を Table 4 に示した。 $\mathrm{O} / \mathrm{C}$ 值は 前処理により変化しなかった。Adaro 原炭の水素化分 解反応から得られた HS の $\mathrm{fa}, \mathrm{H} / \mathrm{C}$ 值と比べて, そ の加熱処理炭の HS では, 前処理温度の増加に従い fa の増加，および H/Cの減少が見られた。しかしなが ら, 水蒸気処理炭のこれらの值の変化は, 加熱処理炭 のそれらの変化よりも少ないことが分かった。一方， $235{ }^{\circ} \mathrm{C}$ 加熱処理炭の值を除いて, Huaipei 炭の加熱, 水蒸気処理炭の水素化分解反応から得られたHSの fa， H/C 值は，処理温度にかかわらずほとんど変化が 見られなかった。

\section{4. 考 察}

\section{1 石炭水素化分解反応における加熱処理の影 響}

石炭分子間，および分子内の酸性官能基間架橋形成 の模式図を Fig. 4 のように考察した。- $\mathrm{COOH}$ 基同士 (a)，および-COOH と-OH 基間（b）の場合は，脱水 により，それぞれ酸無水物，およびエステルが生起す る。さらに $\mathrm{CO}_{2}$ や $\mathrm{CO}$ 生成を伴い, 芳香環炭素間架 橋の形成することが予想された。一方，一OH 基同士 (c) の脱水により，エーテル架橋が生成する。以上か ら, 酸性官能基間の分解は架橋形成と密接な関係があ るといえる。

$80{ }^{\circ} \mathrm{C}$ 以上の加熱処理により石炭のピリジンによる 膨潤率が減少するのは，石炭構造中の酸性官能基間の 架橋形成によるものと考えられている ${ }^{4)}{ }^{5)}$ 。一方, $150 \sim 170{ }^{\circ} \mathrm{C}$ で加熱処理した石炭の熱分解反応におけ るタール収率の増加は, 加熱処理における石炭中の水 素結合の解裂によるものとされている ${ }^{8)}$ 。しかしなが ら, Fig. 2, Fig. 3 に示したように, Adaro 炭の場合は 
Table 4 Aromaticity index (fa) and atomic ratios of $\mathrm{H} / \mathrm{C}$ and $\mathrm{O} / \mathrm{C}$ of $\mathrm{HS}$ constituents derived from the hydrogenolyses of coals

(a) Adaro coal

\begin{tabular}{|c|c|c|c|c|c|c|c|c|c|c|c|}
\hline & \multirow[t]{2}{*}{ Raw coal } & \multicolumn{4}{|c|}{ DT pretreated coals } & \multicolumn{6}{|c|}{ ST pretreated coals } \\
\hline & & $100{ }^{\circ} \mathrm{C}$ & $150^{\circ} \mathrm{C}$ & $200^{\circ} \mathrm{C}$ & $250^{\circ} \mathrm{C}$ & $100{ }^{\circ} \mathrm{C}$ & $150^{\circ} \mathrm{C}$ & $200{ }^{\circ} \mathrm{C}$ & $250^{\circ} \mathrm{C}$ & $300^{\circ} \mathrm{C}$ & $350^{\circ} \mathrm{C}$ \\
\hline $\mathrm{fa}$ & 0.56 & 0.56 & 0.57 & 0.65 & 0.69 & 0.57 & 0.56 & 0.56 & 0.56 & 0.61 & 0.62 \\
\hline $\mathrm{H} / \mathrm{C}$ & 1.16 & 1.17 & 1.17 & 1.04 & 1.02 & 1.17 & 1.18 & 1.17 & 1.17 & 1.12 & 1.08 \\
\hline $\mathrm{O} / \mathrm{C}$ & 0.06 & 0.06 & 0.06 & 0.05 & 0.06 & 0.06 & 0.06 & 0.06 & 0.06 & 0.06 & 0.05 \\
\hline
\end{tabular}

(b) Huaipei coal

\begin{tabular}{|c|c|c|c|c|c|c|c|c|}
\hline & \multirow[t]{2}{*}{ Raw coal } & \multicolumn{3}{|c|}{ DT pretreated coals } & \multicolumn{4}{|c|}{ ST pretreated coals } \\
\hline & & $150^{\circ} \mathrm{C}$ & $200{ }^{\circ} \mathrm{C}$ & $235^{\circ} \mathrm{C}$ & $150^{\circ} \mathrm{C}$ & $200^{\circ} \mathrm{C}$ & $300^{\circ} \mathrm{C}$ & $350^{\circ} \mathrm{C}$ \\
\hline fa & 0.66 & 0.67 & 0.67 & 0.71 & 0.67 & 0.67 & 0.67 & 0.68 \\
\hline $\mathrm{H} / \mathrm{C}$ & 1.01 & 1.01 & 1.02 & 0.95 & 1.01 & 1.02 & 1.01 & 0.99 \\
\hline $\mathrm{O} / \mathrm{C}$ & 0.03 & 0.04 & 0.04 & 0.03 & 0.04 & 0.04 & 0.03 & 0.03 \\
\hline
\end{tabular}

(a) Among - $\mathrm{COOH}$ groups

(b) Between - $\mathrm{COOH}$ and $-\mathrm{OH}$ groups
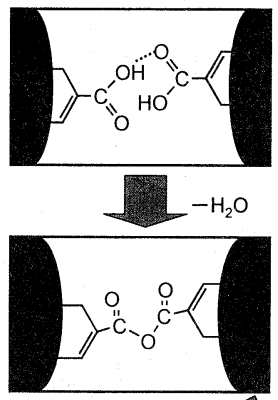

$-\mathrm{CO}_{2},-\mathrm{CO}$
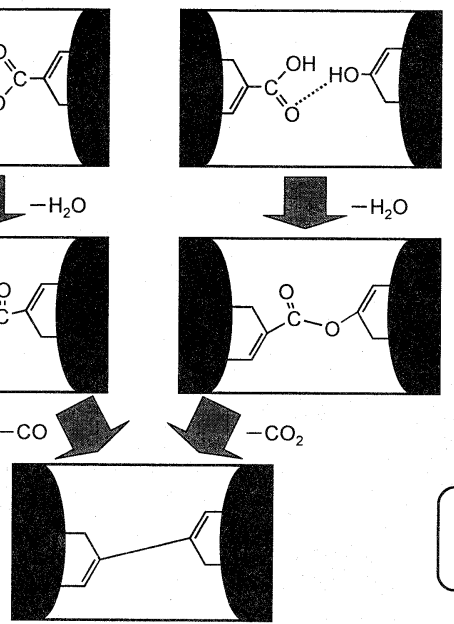

$1-\mathrm{H}_{2} \mathrm{O}$
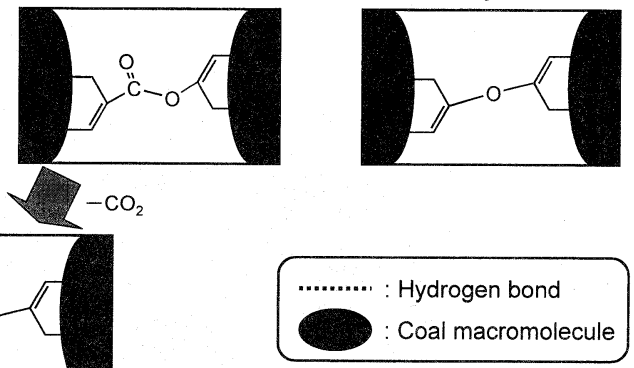

Fig. 4 Crosslinking formation between the acidic groups in coal

$150{ }^{\circ} \mathrm{C}$ 以下，および Huaipei 炭の場合は $200{ }^{\circ} \mathrm{C}$ 以下の 加熱処理炭の水素化分解反応収率では，それぞれの原 炭の収率と比べて変化しなかった。従って, 低石炭化 度炭である Adaro 炭の $150{ }^{\circ} \mathrm{C}$ 以下，および高石炭化 度炭である Huaipei 炭の $200{ }^{\circ} \mathrm{C}$ 以下の加熱処理では, 石炭高分子に結合した酸性官能基間の水素結合の解裂 や架橋形成は，その後の水素化分解反応に影響を与え るほど起こらないものと考えられた。

Adaro 炭の $200{ }^{\circ} \mathrm{C}, 250{ }^{\circ} \mathrm{C}$, および Huaipei 炭の $235{ }^{\circ} \mathrm{C}$ の加熱処理による石炭構造中の含酸素官能基の 化学変化とその水素化分解反応への影響を次のように 考え，それぞれFig. 5, Fig. 6 に示した。これらの温

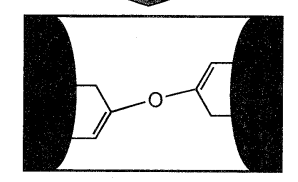

(c) Among $-\mathrm{OH}$ groups
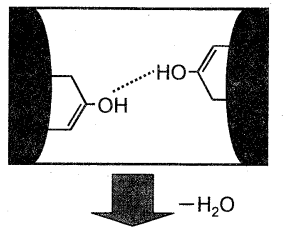

Coal macromolecule
度の加熱処理においては, Fig. 4 のような酸性官能基 間の架橋形成が顕著に起こり，結果として $\mathrm{CO}_{2}, \mathrm{CO}$ 収率の増加につながった。さらに， $\mathrm{CH}_{4}, \mathrm{C}_{2} \mathrm{H}_{6}, \mathrm{C}_{3} \mathrm{H}_{8}$ を発生する架橋反応も起こった。従って，これらの前 処理炭の水素化分解反応においては軽質化の抑制が生 じるため, 重質成分である AI 収率の増加, 軽質成分 である HS 収率の減少が考えられた。さらに, Table 4 に示したように，これらの前処理炭の軽質化反応抑制 の結果, $\mathrm{HS}$ の $\mathrm{fa}$ 值の増加, および $\mathrm{H} / \mathrm{C}$ 值の減少も 見られた。

$200{ }^{\circ} \mathrm{C}$ の加熱処理炭の水素化分解反応収率をそれぞ れの原炭の収率と比べると, Adaro 炭では AI 収率が 

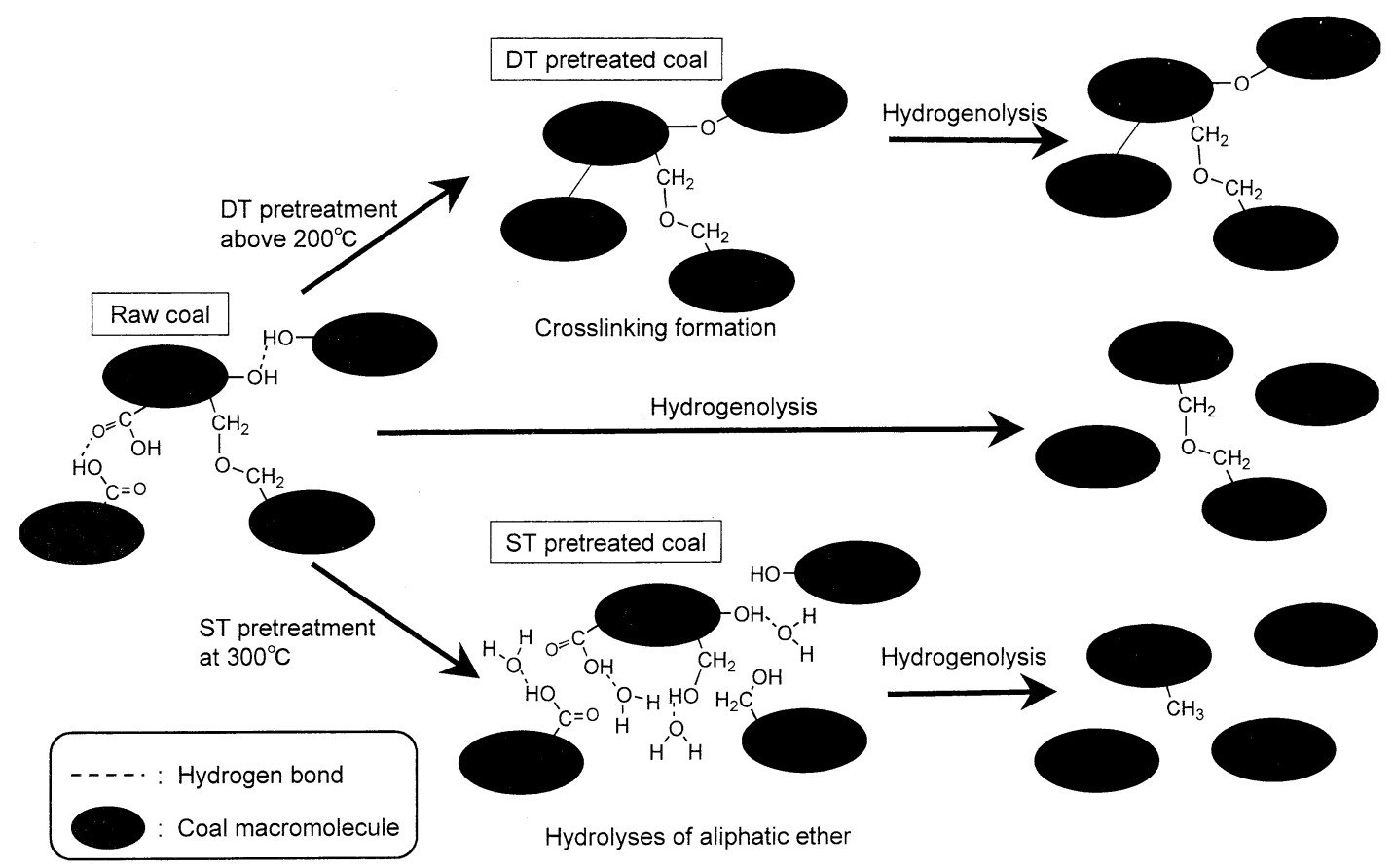

Fig. 5 Schematic representation for structural changes of Adaro coal on DT or ST pretreatment and the effects to the subsequent hydrogenolysis reaction

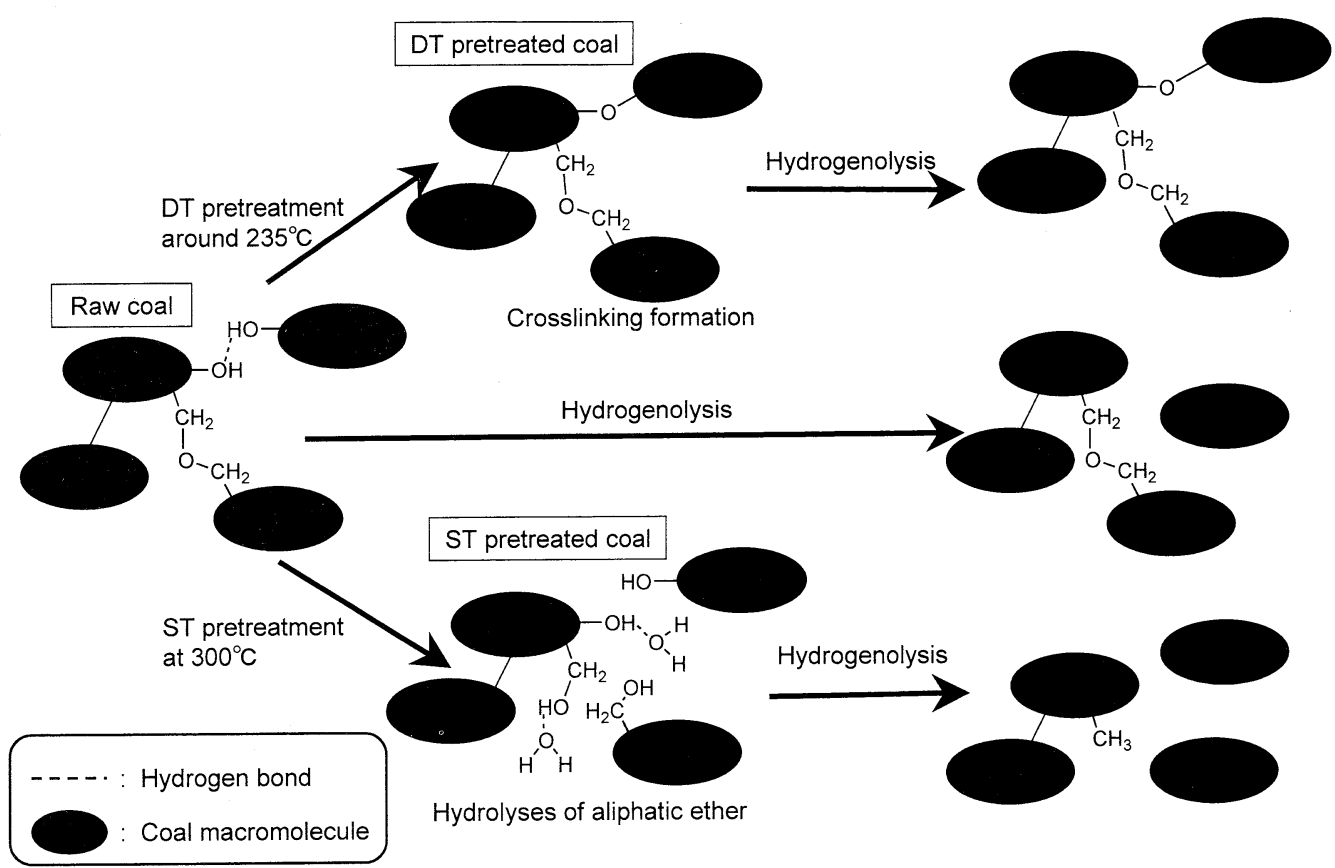

Fig. 6 Schematic representation for structural changes of Huaipei coal on DT or ST pretreatment and the effects to the subsequent hydrogenolysis reaction 
増加したのに対して, Huaipei 炭では変化しなかった。 また, Table 2 から, Adaro 炭の加熱処理に打ける $\mathrm{CO}_{2}$ と $\mathrm{CO}$ 収率は, 各温度において Huaipei 炭のそれ らよりも高いため, オートクレーブ圧力も高くなった と言えよう。従って，水素化分解反応により高収率の AI をもたらす原因となった加熱前処理における酸性 官能基間の架橋形成は，官能基含有率の多い Adaro 炭では $200{ }^{\circ} \mathrm{C}$ 付近から起こり始めるが, 含有率の少な い Huaipei 炭では $235{ }^{\circ} \mathrm{C}$ 付近にならないと起こらない と考えられた。

\section{2 石炭水素化分解反応における水蒸気処理の 影響}

石炭の水中加熱処理においては，水分子と石炭中の 酸性官能基間の水素結合形成により石炭構造は膨潤す るため，石炭架橋構造内にトラップされていた熱分解 フラグメントは，重質化される前に熱水中に抽出され ると考えられている ${ }^{9) \sim 13)}$ 。Table 2 に示したように， Adaro 炭の WS 収率を各処理温度で比較すると， Huaipei 炭の値より高くなった。従って，これも， Huaipei 炭よりも酸性官能基含有率の高い Adaro 炭の 方が，酸性官能基を介した水分子との新たな水素結合 が多く形成され，熱水中へ溶解した分子が多くなるた めと考えられた。また，各温度で比較した水蒸気処理 によるオートクレーブ圧力（Table 2）が両炭で同じ であったのは，水蒸気の圧力が大部分を占めること， および水蒸気処理による両炭間の Gas1 収率の差が加 熱処理と比べて少なかったためであろう。

Fig. 2, Fig. 3 から分かるように, $250^{\circ} \mathrm{C}$ 以下の水蒸 気処理による水素化分解反応収率の変化はいずれの石 炭でも見られなかった。また，水蒸気処理による $\mathrm{CO}_{2}$ 収率（Table 2)，その処理炭の酸性官能基含有率，お よび $\mathrm{H} / \mathrm{C}, \mathrm{O} / \mathrm{C}$ 原子比（Table 3)，処理炭の反応によ る HS の fa 值と H/C 值（Table 4）は，加熱処理によ るそれらの值と比べて，あまり変化しなかった。水分 子は石炭分子内の水素結合の解裂を促進することが報 告されている $\left.{ }^{10)} 11\right)$ 。従って, $250^{\circ} \mathrm{C}$ 以下の水蒸気処理 においては，加えた水分子と石炭中の酸性官能基間の 水素結合が優先的に形成されるため, 加熱処理におい て生じたような架橋形成を伴う酸性官能基の分解が抑 制され，その後の水素化分解反応に及ぼす影響が見ら れなかったと言える。

$250{ }^{\circ} \mathrm{C}$ 以上の水蒸気処理においても，架橋形成を伴 う酸性官能基の分解が水分子と石炭高分子間の水素結 合形成により抑制されたと考えられた。水を用いて石
炭を前処理すると石炭転化率が促進されるのは, 石炭 分子内のエステル架橋の水中脱炭酸 ${ }^{13)}{ }^{14)}$ ，およびエ 一テル架橋の加水分解 12) 14）19）により-OH 基が生成 するためと考えられている。石炭構造内のエーテルやエ ステル型酸素含有率は石炭化度にあまり依存しない20) ことが知られている。

以上から, $300{ }^{\circ} \mathrm{C}$ の水蒸気処理による Adaro 炭, お よび Huaipei 炭構造中の含酸素官能基の化学変化とそ の水素化分解反応への影響を次のように考え，それぞ れ Fig. 5，Fig. 6 に示した。いずれの石炭においても， $300{ }^{\circ} \mathrm{C}$ の水蒸気処理では石炭構造中のジベンジルエー テル型の脂肪族エーテル，およびエステル架橋の加水 分解も起こったため, その後の水素化分解反応におけ る軽質化につながり，重質成分である AI 収率がわず かに減少したと言えよう。

しかしながら, Table 3 に示したように, $350{ }^{\circ} \mathrm{C} の$ 水蒸気処理によりいずれの石炭の-OH 基含有率もわ ずかに減少した。このことから， $350^{\circ} \mathrm{C}$ の水蒸気処理 では，それ以下の温度の処理において抑制されてい た-OH 基間の架橋形成反応が起こりやすくなるため, Fig. 2, Fig. 3 に示したように $300{ }^{\circ} \mathrm{C}$ 水蒸気処理炭の水 素化分解反応に比べて AI 収率がわずかに増加したも のと推測された。このことは, Illinois No.6 炭の $340{ }^{\circ} \mathrm{C}$ 以下のスチーム前処理により, ピリジン抽出率 10) や，液化反応に扔ける n-へキサン可溶分収率 ${ }^{15)}$ の 増加は起こるが, $350{ }^{\circ} \mathrm{C}$ 以上の処理炭になると, これ らの収率は未処理炭の值と変わらないという報告と同 じ傾向を示している。

\section{5. 結 言}

水蒸気前処理による Adaro 亜瀝青炭と Huaipei 瀝青 炭の水素化分解反応特性を，石炭の加熱前処理による 場合と比較検討した。石炭構造中の含酸素官能基の化 学変化の状態とその水素化分解反応への影響は以下の ように処理方法, 処理温度, および石炭化度により変 わることが分かった。

(1) Adaro 炭の $150{ }^{\circ} \mathrm{C}$ 以下，および Huaipei 炭の $200{ }^{\circ} \mathrm{C}$ 以下の加熱前処理に扔いては，酸性含酸素 官能基（カルボキシル基とフェノール性水酸基） 間の水素結合の解裂，および架橋形成は，その後 の水素化分解反応に影響を及ぼすほど起こらなか った。

(2) Adaro 炭の $200{ }^{\circ} \mathrm{C}$ と $250{ }^{\circ} \mathrm{C}$, および Huaipei 炭 の $235{ }^{\circ} \mathrm{C}$ の加熱前処理により, 処理炭の水素化分 解反応における軽質化が抑制された。これは，低 
石炭化度炭である Adaro 炭に多く含まれている 酸性官能基間の架橋形成が $200{ }^{\circ} \mathrm{C}$ 付近から起こり 始めたのに対して，高石炭化度炭であり，官能基 含有率の少ないHuaipei 炭構造内の架橋形成は $235{ }^{\circ} \mathrm{C}$ 付近にならないと起こらないためである。

(3) $250{ }^{\circ} \mathrm{C}$ 以下の水蒸気前処理に扔いては, 石炭中 の酸性官能基と水分子間に新たに水素結合が形成 されるため，架橋形成を伴う酸性官能基間の分解 は抑制された。従って,これらの処理炭の水素化 分解反応収率はそれぞれの原炭と比べて変化が見 られなかった。

(4) $300{ }^{\circ} \mathrm{C}$ の水蒸気前処理により石炭構造中の脂肪 族エーテル，およびエステル架橋の加水分解が起 こり, 処理炭の水素化分解反応においてわずかに 軽質化が促進された。しかしながら， $350{ }^{\circ} \mathrm{C}$ の水 蒸気前処理では架橋形成が起こりやすくなるため に，その軽質化への効果は消失した。

\section{謝 辞}

本研究をまとめるにあたって, 本学学生 竹原 充, 小俣孝史，恩田大五郎君の協力を得たことに感謝致し ます。

\section{文献}

1) Larsen, J. W., Green, T. K., Kovac, J., J. Org. Chem., 50, 4729 (1985)

2 ). Hayashi, J.-i., Matsuo, Y., Kusakabe, K., Morooka, S., Energy Fuels, 9, 284 (1995)

3 ) Sugano, M., Mashimo, K., Wainai, T., Proceedings, 9th International Conference on Coal Science, p.273 (1997)

4 ) Solomon, P. R., Serio, M. A., Despande, G. V., Kroo,
E., Energy Fuels, 4, 42 (1990)

5 ) Suuberg, E. M., Otake, Y., Yun, Y., Deevi, S. C., Energy Fuels, 7, 384 (1993)

6 ) Nishioka, M., Fuel, 73, 57 (1994)

7 ) 持田 勲, 油布 淳, 坂西欣也, 光来要三, 下原 孝章, 燃協誌, 65, 1020 (1986)

8 ) Miura, K., Mae, K., Sakurada, K., Hashimoto, K., Energy Fuels, 6, 16 (1992)

9 ) Deshpande, G. V., Holder, G. D., Bishop, A. A., Gopal, J., Wender, I., Fuel, 63, 956 (1984)

10) Graff, R. A., Brandes, S. D., Energy Fuels, 1, 84 (1987)

11) Bienkowski, P. R., Narayan, R., Greenkorn, R. A., Chao K.-C., Ind. Eng. Chem. Res., 26, 202 (1987)

12) Mapstone, J. O., Energy Fuels, 5, 695 (1991)

13）阿尻雅文, 長島 進, 四分一 宏, 新井邦夫, 宍 戸昌広，日工市誌，75,742（1996）

14) Artok, L., Schobert, H. H., Nomura, M., Erbatur, O., Kidena, K., Energy Fuels, 12, 1200 (1998)

15) Ivanenko, O., Graff, R. A., Balogh-Nair, V., Brathwaite, C., Energy Fuels, 11, 206 (1997)

16) Townsend, S. H., Abraham, M. A., Huppert, G. L., Klein, M. T., Paspek, S. C., Ind. Eng. Chem. Res., 27, 143 (1988)

17) Siskin, M., Brons, G., Vaughn, S. N., Katritzky, A. R., Balasubramanian, M., Energy Fuels, 4, 488 (1990)

18) Brown, J. K., Ladner, W. R., Fuel, 39, 87 (1960)

19) Murakami, K., Ozaki, J.-i., Nishiyama, Y., Fuel Process. Technol, 43, 95 (1995)

20) Jung, B., Stachel, S., Calkins, W. H., Prepr. Am. Chem. Soc., Div. Fuel Chem., 36 (3) , 869 (1991) 


\title{
Effects of Thermal or Steam Pretreatment on the Hydrogenolysis Reactivities of Coals
}

\author{
Motoyuki SUGANO and Kiyoshi MASHIMO \\ $\left(\begin{array}{l}\text { Department of Materials and Applied Chemistry, } \\ \text { College of Science and Technology, Nihon University }\end{array}\right)$
}

SYNOPSIS : - It has been widely reported that the hydrothermal pretreatment of coal promotes the subsequent conversion of coal. In this study, the effects of dry thermal (DT) or steam (ST) pretreatment of Adaro subbituminous and Huaipei bituminous coals on the chemical changes of oxygen containing functional groups in coals were discussed with the yields of the subsequent hydrogenolysis reactions of coals. As discussed below, it was considered that the effects of pretreatments varied with the treated temperature and the coal rank. During DT pretreatments of Adaro coal below $150{ }^{\circ} \mathrm{C}$ and Huaipei coal below $200{ }^{\circ} \mathrm{C}$, the cleavage of hydrogen bonds did not affect the subsequent hydrogenolysis reactions. In DT pretreatments of Huaipei coal at $235{ }^{\circ} \mathrm{C}$ and Adaro coal at $200{ }^{\circ} \mathrm{C}$ and $250{ }^{\circ} \mathrm{C}$, the crosslinking formations among the acidic groups (carboxyl and phenolic hydroxyl groups) in coals developed, followed by the suppression of hydrogenolysis reactions of coals. The contents of the acidic groups in lower rank Adaro coal were higher than those of higher rank Huaipei coal. It was indicated that the crosslinking formations of Huaipei coal occurred at around $235{ }^{\circ} \mathrm{C}$, while those of Adaro coal started at the lower temperature, around $200{ }^{\circ} \mathrm{C}$. However, the crosslinking formations occurred less during ST pretreatments of coals below $250{ }^{\circ} \mathrm{C}$ because the hydrogen bonds were freshly formed between the acidic groups and water molecules. Therefore, there was no change between the yields of hydrogenolysis reactions of ST pretreated coals and those of the respective raw coals. Accordingly, for both coals, the hydrolyses of ester and ether crosslinks in coal structures also occurred in ST pretreatment at $300{ }^{\circ} \mathrm{C}$, which resulted upgrading on the subsequent hydrogenolysis reactions. However, the crosslinking formation occurred in ST pretreatments of both coals at $350{ }^{\circ} \mathrm{C}$, followed by the suppression of the upgrading on the hydrogenolysis reactions of the pretreated coals.

\section{Key Words}

Coal hydrogenolysis, Coal structural change, Dry thermal pretreatment, Steam pretreatment 